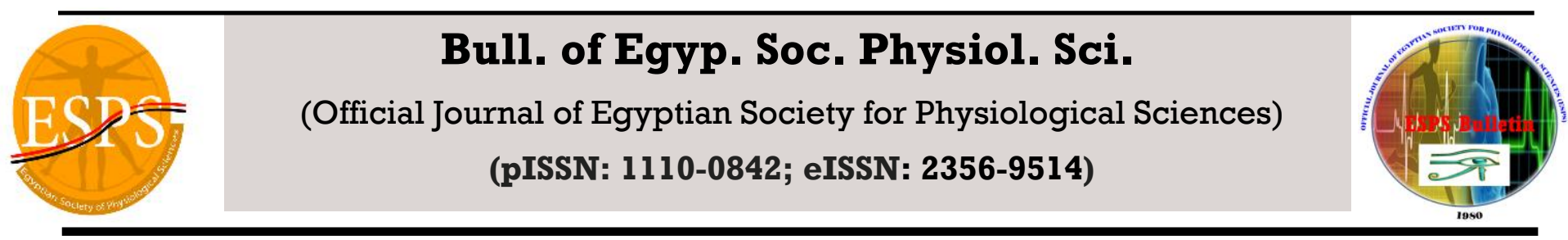

\title{
Effect of Kv7 channel Modulators on the Contractility of Diabetic Rat Stomach in- vitro
}

Gehan A. Shaker, Shaimaa A. Gad, Atef Mansour, and Sabry Gad

Department of Medical Physiology/ Faculty of Medicine/Mansoura University, Mansoura, Egypt

Received: 27 Dec 2018

Accepted: 1 Feb 2019

Available online: 1 Mar 2019

\section{Keywords}

- Retigabine $\quad\left(\mathrm{K}_{\mathrm{V}} 7\right.$ opener) and XE-991

(Kv7 blocker)

- Gastric motility

- STZ- Induced diabetes

\section{Abstract}

Diabetic GI complications as gastric and colonic motility disturbances occur commonly in DM if it is of long duration and/or treated inappropriately. Recently, the importance of Kv7 (KCNQ) channels in controlling and regulating muscle tone and contraction in different tissues including the GI tract is highlighted by different studies. So, the aim of the present work is to study the effect of $\mathrm{K}_{\mathrm{V}} 7$ channel modulators, Retigabine ( $\mathrm{K}_{\mathrm{V}} 7$ opener) and XE-991 ( $\mathrm{K}_{\mathrm{V}} 7$ blocker), on motility of both fundal and corpal gastric segments in rate model of type I DM. Methods: 24 Male Sprague Dawley rats were divided into 2 main groups: (I) control and (II) diabetic group ( $\mathrm{n}=12$ ) Each group was subdivided into 2 subgroups according to the used segment whether fundus or corpus. Each segment group was treated with retigabine ( $\mathrm{K}_{\mathrm{V}} 7$ opener) and XE-991 (K 7 blocker) on basal and cholinergic stimulated motility. The motility was recorded in-vitro using the Power Lab data acquisition system. Results: Diabetic stomach significantly showed higher basal amplitude and higher basal fundal frequency of contractions when compared with the control group. Diabetic gastric response to A.ch is significantly higher as compared to control group. Retigabine, significantly decreases the spontaneous contractility of gastric fundal and corpal smooth muscle strips in diabetic and control rats but diabetic group exhibits significant more decrease in contractility than the control one. Also, retigabine significantly decreases the contractility of the cholinergic stimulated fundal and corpal strips with significant more decrease in contraction amplitude in diabetic corpus than control one .XE-991, significantly increases the spontaneous contractility of gastric fundal and corpal smooth muscle strips in diabetic and also in control rats but diabetic group exhibits significant more increase in contraction in response to XE991 than control . Also, XE-991 after A.ch significantly increases the amplitude of fundal and corpal smooth muscle contractility of both diabetic and control groups with significant higher contraction in diabetic group, however there is no increase in the tone after A.ch in either groups. Conclusion: $\mathrm{K}_{\mathrm{V}} 7$ channel modulators could affect the gastric activity in type I diabetic rats , a possible new strategy that might be involved in management of diabetic gastro-enteropathy

Corresponding author: Gehan A. Shaker Department of Medical physiology, Faculty of Medicine, Mansoura University, Mansoura, Egypt, Email: gehanshaker@mans.edu.eg; Mob., +20502164462 



\section{INTRODUCTION}

Diabetes Mellitus (DM) is a very common disease. Usually, it is associated with gastrointestinal (GI) manifestations which interfere with the daily life of the patient causing discomfort and disability. Diabetes affects nearly every part in the GIT from the esophagus to the rectum but the definite mechanism still unclear. The GI symptoms include heart burn, nausea, vomiting, abdominal pain, constipation and diarrhea $(1 ; 2)$. Recently, not only autonomic neuropathy is the cause but enteric nervous system, gut microbiota and direct effect on GIT smooth muscles are also involved in the pathophysiology of the GI symptoms in diabetes (3).

$\mathrm{K}^{+}$channels play an important role in the functions of nearly all excitable cells as muscle cells and neurons (4). Activation or inhibition of these channels leads to hyperpolarization or depolarization of the cell membrane, respectively. These changes determine the contractility of the smooth muscle cells through either decreasing $\mathrm{Ca}^{2+}$ influx via voltage-gated $\mathrm{Ca}^{2+}$ channel $\left(\mathrm{Ca}_{\mathrm{v}} 1.2\right)$ causing smooth muscles relaxation or increasing $\mathrm{Ca}^{2+}$ influx through the same channel type causing smooth muscles contraction $(5 ; 6 ; 7)$. Recently, the importance of $\mathrm{K}_{\mathrm{v}} 7$ (KCNQ) channels in controlling and regulating muscle tone and contraction in different tissues in the body including stomach and colon is highlighted by different studies.

So, as a further step in studying the possible mechanism that might participate in occurrence or controlling diabetic GI changes, the present work aimed to investigate whether the modulation of $\mathrm{K}_{\mathrm{v}} 7$ channels by their agonist and blocker could affect the gastric smooth muscle motility changes in diabetic rats.

\section{Experimental plan:}

24 adult male Sprague Dawley rats weighing 200-250 grams were included in this study. The study was approved by the research ethics committee, faculty of medicine, Mansoura University, Egypt.

\section{Chemicals:}

- Acetylcholine Chloride, $\left(\mathrm{C}_{7} \mathrm{H}_{16} \mathrm{CINO}_{2}\right)$, freshly prepared by dissolving 1.09 milligrams in 2 milliliters distilled water,

- Streptozotocin, freshly prepared by dissolving in cold $\mathrm{Na}$ citrate buffer $(\mathrm{PH}=4.2)$.

- Retigabine, it is $\mathrm{K}_{\mathrm{V}} 7$ channel opener. freshly prepared by dissolving 1.092 milligrams in dimethyl sulfoxide in a concentration of $0.025 \%$ then diluted with distilled water up to 3 milliliters (8).

- XE-991, it is $\mathrm{K}_{\mathrm{V}} 7$ channel blocker. freshly prepared by dissolving 1.13 milligrams in dimethyl sulfoxide in a concentration of $0.025 \%$ then diluted with distilled water up to 1 milliliter (8).

All chemicals were in a powder form that purchased from Sigma Aldrich, Egypt.

\section{Experimental groups:}

Twenty four rats were divided into two main groups: ( $\mathrm{n}=12$ per group) I) control group. II) diabetic group.

Each group was subdivided into 2 subgroups based on the examined segment (gastric fundus and gastric corpus), ( $\mathrm{n}=6$ per group):

The study consists of the following experiments on rat stomach in control (I) and diabetic (II) groups: 
A. The effect of retigabine $\left(\mathrm{K}_{\mathrm{V}} 7\right.$ opener) (in a dose of 8 micromole / 30 milliliter organ bath)

(8) on basal (spontaneous) contractility .

B. The effect of retigabine on cholinergic stimulated contractility

C. The effect of XE-991 ( $\mathrm{K}_{\mathrm{V}} 7$ blocker) (in a dose of 10 micromole / 30 milliliter organ bath) (8) on basal (spontaneous) contractility .

D. The effect of XE-991 on cholinergic stimulated contractility.

\section{Induction of type I diabetes:}

Animals were fasted for $16 \mathrm{~h}$, and injected intraperitoneal with $50 \mathrm{mg} / \mathrm{kg}$ freshly prepared Streptozotocin as a single dose. (Sigma Aldrich, SO130- 1G). STZ was dissolved in $0.1 \mathrm{~mol} / \mathrm{L}$ citric buffer ( $\mathrm{pH}$ 4.2) (9). Rats were allowed to drink $10 \%$ glucose solution for 24-hours following STZ injection to avoid STZ induced initial hypoglycemia (10). Blood glucose levels were estimated $72 \mathrm{~h}$ after STZ injection via rat tail vein blood samples using a Bionime Glucometer. Rats with blood glucose levels $>300 \mathrm{mg} / \mathrm{dl}$ were included in the study (11). Diabetic animals were kept without treatment for 8 weeks to reveal complications of diabetes (12).

\section{Tissue preparation:}

Overnight fasted rats (with free access to water) were anaesthetized by diethyl ether and decapitated by cervical dislocation. Midline incision in the anterior abdominal wall was done then the stomach was dissected and opened through the greater curvature. The contents were washed out with Krebs solution then gastric specimens were divided as longitudinal fundal and corpal muscle strips $(3 \times 20 \mathrm{~mm})$. the strips were prepared in Krebs solution of the following composition (in $\mathrm{mM}$ concentrations): $\mathrm{NaCl} 118.5$,
NaHCO3 25, $\mathrm{KCl} 4.8, \mathrm{MgSO} 4$ 1.2, $\mathrm{KH} 2 \mathrm{PO} 4$ 1.2, $\mathrm{CaCl} 21.9$ and glucose 10.1 (pH 7.4) (Ipavec, et.al., 2011). Then, it were suspended in $30 \mathrm{~mL}$ organ bath containing gassed $\left(95 \% \mathrm{O}_{2}\right.$ and $5 \%$ $\left.\mathrm{CO}_{2}\right)$ Krebs solution, maintained at $37^{\circ} \mathrm{C}$ and allowed for equilibration time (13).

\section{Equipment:}

* Organ bath: It consists of a central tube that has a 30-ml capacity. A water container surrounded the tube and its temperature was always $37^{\circ} \mathrm{C}$ through an electrical thermostatic heater. Pinning of a hollow-hooked stainless-steel tube was done with its main head directed downwards to be placed easily into the central tube to supply the solution with gas and fix the specimens simultaneously.

*Gas supplier : It was connected to the hollow tube by a screw clamp which was adjusted to supply 2 bubbles per second, that aerate the specimens and preserve its viability during the experiment.

*Power Lab recording unit 4/30 : The gut contractility was recorded by using a Power Lab recording unit (4/30) with its isotonic transducer (model: TRO015) that was connected to Bridge Amplifier. Recording data was performed via Lab chart 7 software.

\section{Tissue fixation and basal recording:}

The selected gastric specimens were fixed vertically from both ends through clamping their lower end at the depth of the organ bath with the stainless-steel tube while their upper end was connected to a pin which was connected to the isotonic transducer of the Power Lab recording unit by a thread and hook. The specimens were under tension that equals one gram and suspended in that bath supplied with the gassed Krebs 
solution at $37^{\circ} \mathrm{C}$. Then equilibration period was allowed to accommodate the new medium until spontaneous rhythmic contractions (basal contractility) were recorded. The specimens were allowed to equilibrate for 20 minutes in the organ bath solution and the incubation media were frequently changed at 10 minutes interval (involving both, equilibration period and in between experimental steps).

\section{Statistical analysis}

The recorded figures were analyzed by Lab Chart Reader 8. Data analysis was done by the statistical package for social science (SPSS), version 22. (ANOVA) with post hoc Tukey test was used for analysis of variance and data were expressed as Mean $\pm \mathrm{SD}$.

N.B: Interval of confidence equals $95 \%$ and significant $\mathrm{P}$ value $<0.05$.

\section{Results}

The results were gathered from the recorded curves of gastric contractility. They are listed in the form of figures and tables, involving amplitude, tone and frequency of muscle contraction. Measurements were in millimeter (mm) vertical-length for the amplitude, in $\mathrm{mm}$ up $(+\mathrm{ve})$ or down (-ve) to the zeroed base line $(0 \mathrm{~mm})$ for the tone and cycle per second for the frequency.

In the current study, DM significantly increased the basal amplitude of gastric fundal and corpal contractility and only significantly increased the frequency of diabetic fundal contractions as compared to the control group.

\section{I-Gastric fundus}

Effect of $\mathrm{K}_{\mathrm{V}} 7$ modulators on gastric fundal smooth muscle strips motility in control and diabetic rats: Table(1)
A.Ch significantly reduced the amplitude of control gastric fundal contractility from 0.00313 $\mathrm{mm}$ to $0.0021 \mathrm{~mm}(\mathrm{P}=0.004)$. The tone was significantly elevated by $0.03 \mathrm{~mm}(\mathrm{P}=0.004)$. It also significantly reduced the amplitude of diabetic fundal contractility from $0.0043 \mathrm{~mm}$ to $0.0025 \mathrm{~mm}$ $(\mathrm{P}=0.012)$. The tone was significantly elevated by $0.093 \mathrm{~mm}(\mathrm{P}<0.001)$

Effect of retigabine on basal and A.Ch. stimulated fundal motility: Table(1)

Retigabine $(8 \mathcal{M} \mathrm{M} / 30 \mathrm{ml}$ organ bath) significantly reduced the amplitude of control gastric fundal contractility from $0.00313 \mathrm{~mm}$ to $0.0021 \mathrm{~mm}(\mathrm{P}=0.032)$. The tone was significantly reduced by $0.0157 \mathrm{~mm}(\mathrm{P}=0.004)$. It produced insignificant decrease in the frequency. Also, retigabine significantly reduced the amplitude of diabetic gastric fundal contractility from 0.0043 $\mathrm{mm}$ to $0.0027 \mathrm{~mm}(\mathrm{P}<0.001)$. The tone was significantly reduced by $0.036 \mathrm{~mm}(\mathrm{P}<0.001)$. It produced insignificant decrease in the frequency.

Retigabine after A.ch significantly reduced the amplitude of control fundal contractions from $0.00313 \mathrm{~mm}$ to $0.0019 \mathrm{~mm}(\mathrm{P}=0.001)$ in comparison to the spontaneous contractility. The tone was significantly reduced by $0.063 \mathrm{~mm}$ $(\mathrm{P}<0.001)$ as regard to contractions following A.ch and by $0.033 \mathrm{~mm}(\mathrm{P}<0.001)$ as regard to spontaneous contractility. It non-significantly reduced the amplitude of control fundal contraction in comparison to contractions next to A.ch. The frequency was insignificantly reduced.

In diabetic rats, retigabine after A.ch induced significant reduction in the amplitude of fundal contractions from $0.0043 \mathrm{~mm}$ to $0.002 \mathrm{~mm}$ $(\mathrm{P}=0.017)$ in comparison to spontaneous contractility. Also, the tone was significantly 
reduced by $0.138 \mathrm{~mm}(\mathrm{P}<0.001)$ as regard to contractions after A.ch and by $0.045 \mathrm{~mm}$ $(\mathrm{P}<0.001)$ when compared with the basal contractions. It produced no change in the amplitude of diabetic fundal contractions when compared with contractions after A.ch, and insignificantly decreased the frequency.

Effect of XE-991 on basal and A.Ch stimulated fundal motility: Table (1)

XE-991 produced significant increase in the basal amplitude of gastric fundal contractions of control group from $0.00313 \mathrm{~mm}$ to $0.0106 \mathrm{~mm}$ $(\mathrm{P}=0.001)$, significant increase in the tone by $0.0036 \mathrm{~mm}(\mathrm{P}<0.001)$ but insignificant decrease in the frequency. It also produced significant increase in the amplitude of basal gastric fundal contractions of diabetic group from $0.0043 \mathrm{~mm}$ to $0.0055 \mathrm{~mm}(\mathrm{P}=0.039)$, significant increase in the tone by $0.011 \mathrm{~mm}(\mathrm{P}=0.001)$ but insignificant increase in the frequency.

XE-991 after A.ch significantly enhanced the amplitude of control fundal contractility from $0.002 \mathrm{~mm}$ to $0.004 \mathrm{~mm}(\mathrm{P}<0.001)$ as regard to contractions following A.ch. and from 0.00313 $\mathrm{mm}$ to $0.004 \mathrm{~mm} \quad(\mathrm{P}<0.001)$ as regard to spontaneous contractility. Furthermore, the tone was significantly reduced by $0.018 \mathrm{~mm}(\mathrm{P}=0.032)$ as regard to contractions next to A.ch but was nonsignificantly increased as regard to the spontaneous contractility. The frequency was insignificantly increased

In diabetic rats, XE-991 after A.ch significantly enhanced the amplitude of diabetic fundal contractility from $0.0025 \mathrm{~mm}$ to $0.0077 \mathrm{~mm}$ $(\mathrm{P}<0.001)$ as regard to contractions following A.ch and from $0.0043 \mathrm{~mm}$ to $0.0077 \mathrm{~mm}(\mathrm{P}<0.001)$ as regard to the spontaneous contractility. The tone also was significantly reduced by $0.08 \mathrm{~mm}$ $(\mathrm{P}<0.001)$ in comparison with contractions following A.ch but non-significantly increased as regard to the spontaneous contractility. The frequency was insignificantly increased

\section{II-Gastric corpus}

\section{Effect of KV7 modulators on gastric corpal} smooth muscle strips motility in control and diabetic rats: Table (2):

Acetylcholine non-significantly reduced the amplitude of control gastric corpus contractility from $0.0031 \mathrm{~mm}$ to $0.0023 \mathrm{~mm}$. The tone was significantly elevated by $0.054 \mathrm{~mm}(\mathrm{P}=$ 0.035). It also produced significant reduction in the amplitude of diabetic gastric corpus contractility from $0.0071 \mathrm{~mm}$ to $0.0049 \mathrm{~mm}$ $(\mathrm{P}=0.005)$. The tone was significantly elevated by $0.103 \mathrm{~mm}(\mathrm{P}<0.001)$.

I-Effect of retigabine on basal and A.ch. stimulated corporal motility:Table (2)

Retigabine $(8 \mathcal{M} \mathrm{M} / 30 \mathrm{ml}$ organ bath) significantly reduced the amplitude of control gastric corpus contractility from $0.0031 \mathrm{~mm}$ to $0.0019 \mathrm{~mm}(\mathrm{P}<0.001)$, the tone was significantly reduced by $0.023 \mathrm{~mm}(\mathrm{P}=0.02)$. It produced insignificant increase in the frequency. It also significantly reduced the amplitude of diabetic gastric corpus contractility from $0.0071 \mathrm{~mm}$ to $0.0052 \mathrm{~mm}(\mathrm{P}=0.013)$, the tone was significantly reduced by $0.071 \mathrm{~mm}(\mathrm{P}<0.001)$. It produced insignificant increase in the frequency. 
Table (1): Effect of $\mathrm{K}_{\mathrm{v}} 7$ modulators on gastric fundal smooth muscle strips motility in control and diabetic rats

\begin{tabular}{|c|c|c|c|c|c|c|c|c|c|c|c|c|}
\hline \multicolumn{7}{|c|}{ Control group } & \multicolumn{6}{|c|}{ Diabetic group } \\
\hline & $\begin{array}{l}\text { Basal } \\
n=24\end{array}$ & $\begin{array}{c}\text { Retigabine } \\
\mathrm{n}=6\end{array}$ & $\begin{array}{c}\text { XE-991 } \\
n=6\end{array}$ & $\begin{array}{l}\text { A.ch } \\
n=12\end{array}$ & $\begin{array}{c}\text { Retigabine } \\
n=6\end{array}$ & $\begin{array}{c}\text { XE-991 } \\
n=6\end{array}$ & $\begin{array}{l}\text { Basal } \\
n=24\end{array}$ & $\begin{array}{c}\text { Retigabine } \\
n=6\end{array}$ & $\begin{array}{c}\text { XE-991 } \\
n=6\end{array}$ & $\begin{array}{l}\text { A.ch } \\
n=12\end{array}$ & $\begin{array}{c}\text { Retigabine } \\
\mathrm{n}=6\end{array}$ & $\begin{array}{c}\text { XE-991 } \\
n=6\end{array}$ \\
\hline Amplitude & $\begin{array}{l}0.00313 \\
\pm 0.0001\end{array}$ & $\begin{array}{c}0.0021 \\
\pm 0.00006\end{array}$ & $\begin{array}{l}0.0106 \\
\pm 0.002\end{array}$ & $\begin{array}{c}0.0021 \\
\pm 0.0001\end{array}$ & $\begin{array}{c}0.0019 \\
\pm 0.0003\end{array}$ & $\begin{array}{c}0.004 \\
\pm 0.0005\end{array}$ & $\begin{array}{c}0.0043 \\
\pm 0.0004\end{array}$ & $\begin{array}{c}0.0027 \\
\pm 0.0004\end{array}$ & $\begin{array}{c}0.0055 \\
\pm 0.0016\end{array}$ & $\begin{array}{c}0.0025 \\
\pm 0.0002\end{array}$ & $\begin{array}{c}0.002 \\
\pm 0.0002\end{array}$ & $\begin{array}{l}0.0077 \\
\pm 0.002\end{array}$ \\
\hline $\begin{array}{l}\text { P1 } \\
\text { P2 } \\
\text { P3 }\end{array}$ & $\begin{array}{l}- \\
- \\
-\end{array}$ & $\begin{array}{c}0.032 \\
-\end{array}$ & $\begin{array}{c}0.001 \\
- \\
-\end{array}$ & $\begin{array}{c}0.004 \\
- \\
-\end{array}$ & $\begin{array}{c}0.001 \\
\mathrm{NS} \\
-\end{array}$ & $\begin{array}{l}<0.001 \\
<0.001 \\
-\end{array}$ & - & $\begin{array}{c}<0.001 \\
- \\
<0001\end{array}$ & $\begin{array}{c}0.039 \\
- \\
<0001\end{array}$ & $\begin{array}{c}0.012 \\
- \\
\mathrm{NS}\end{array}$ & $\begin{array}{c}0.017 \\
\text { NS }\end{array}$ & $\begin{array}{l}<0.001 \\
<0.001 \\
<0.001\end{array}$ \\
\hline Tone & 0 & $\begin{array}{l}-0.0157 \\
\pm 0.002\end{array}$ & $\begin{array}{l}0.0036 \\
\pm 0.001\end{array}$ & $\begin{array}{c}0.03 \\
\pm 0.005\end{array}$ & $\begin{array}{l}-0.033 \\
\pm 0.01\end{array}$ & $\begin{array}{c}0.011 \\
\pm 0.0017\end{array}$ & 0 & $\begin{array}{l}-0.036 \\
\pm 0.01\end{array}$ & $\begin{array}{c}0.011 \\
\pm 0.0006\end{array}$ & $\begin{array}{c}0.093 \\
\pm 0.0007\end{array}$ & $\begin{array}{l}-0.045 \\
\pm 0.01\end{array}$ & $\begin{array}{c}0.009 \\
\pm 0.001\end{array}$ \\
\hline $\begin{array}{l}\text { P1 } \\
\text { P2 } \\
\text { P3 }\end{array}$ & $\begin{array}{l}- \\
-\end{array}$ & $\begin{array}{c}0.004 \\
- \\
-\end{array}$ & $\begin{array}{c}<0.001 \\
- \\
-\end{array}$ & $\begin{array}{c}0.004 \\
- \\
-\end{array}$ & $\begin{array}{c}<0.001 \\
<0.001 \\
-\end{array}$ & $\begin{array}{c}\mathrm{NS} \\
0.032 \\
-\end{array}$ & $\begin{array}{l}- \\
-\end{array}$ & $\begin{array}{c}<0.001 \\
- \\
<0.001\end{array}$ & $\begin{array}{c}0.001 \\
- \\
0.014\end{array}$ & $\begin{array}{c}<0.001 \\
- \\
<0.001\end{array}$ & $\begin{array}{c}<0.001 \\
<0.001 \\
\text { NS }\end{array}$ & $\begin{array}{c}\mathrm{NS} \\
<0.001 \\
\mathrm{NS}\end{array}$ \\
\hline Frequency & $\begin{array}{l}0.242 \\
\pm 0.08\end{array}$ & $\begin{array}{l}0.192 \\
\pm 0.08\end{array}$ & $\begin{array}{c}0.15 \\
\pm 0.04\end{array}$ & - & $\begin{array}{l}0.239 \\
\pm 0.03\end{array}$ & $\begin{array}{c}0.27 \\
\pm 0.02\end{array}$ & $\begin{array}{l}0.313 \\
\pm 0.04\end{array}$ & $\begin{array}{c}0.275 \\
\pm 0.027\end{array}$ & $\begin{array}{l}0.326 \\
\pm 0.02\end{array}$ & - & $\begin{array}{l}0.309 \\
\pm 0.03\end{array}$ & $\begin{array}{c}0.314 \\
\pm 0.014\end{array}$ \\
\hline $\begin{array}{l}\text { P1 } \\
\text { P3 }\end{array}$ & $\overline{-}$ & $\begin{array}{l}\mathrm{NS} \\
-\end{array}$ & $\begin{array}{l}\mathrm{NS} \\
-\end{array}$ & - & $\begin{array}{l}\mathrm{NS} \\
-\end{array}$ & $\begin{array}{l}\mathrm{NS} \\
-\end{array}$ & $\overline{0.001}$ & $\begin{array}{l}\text { NS } \\
\text { NS }\end{array}$ & $\begin{array}{c}\mathrm{NS} \\
<0.001\end{array}$ & - & $\begin{array}{l}\mathrm{NS} \\
\mathrm{NS}\end{array}$ & $\begin{array}{l}\text { NS } \\
\text { NS }\end{array}$ \\
\hline
\end{tabular}

values expressed as mean \pm standard deviation, $\mathrm{n}=$ number of specimens, $\mathrm{NS}=$ non-significant, $\mathrm{P} 1=$ probability of significance compared to the basal, $\mathrm{P} 2=$ probability of significance compared to A.ch, P3= probability of significance between control and diabetic groups, significant at $<0.05$.

\begin{tabular}{|c|c|c|c|c|c|c|c|c|c|c|c|c|}
\hline \multicolumn{13}{|c|}{ Table (2): Effect of Kv7 modulators on gastric corpal smooth muscle strips motility in control and diabetic rats } \\
\hline \multicolumn{7}{|c|}{ Control group } & \multicolumn{6}{|c|}{ Diabetic group } \\
\hline & $\begin{array}{l}\text { Basal } \\
n=24\end{array}$ & $\begin{array}{c}\text { Retigabine } \\
n=6\end{array}$ & $\begin{array}{c}\text { XE-991 } \\
n=6\end{array}$ & $\begin{array}{l}\text { A.ch } \\
n=12\end{array}$ & $\begin{array}{c}\text { Retigabine } \\
n=6\end{array}$ & $\begin{array}{c}\text { XE-991 } \\
n=6\end{array}$ & $\begin{array}{l}\text { Basal } \\
n=24\end{array}$ & $\begin{array}{c}\begin{array}{c}\text { Retigabine } \\
\mathrm{n}=6\end{array} \\
\text { (n) }\end{array}$ & $\begin{array}{c}\text { XE-991 } \\
n=6\end{array}$ & $\begin{array}{l}\text { A.ch } \\
n=12\end{array}$ & $\begin{array}{c}\text { Retigabine } \\
\mathrm{n}=6\end{array}$ & $\begin{array}{c}\text { XE-991 } \\
n=6\end{array}$ \\
\hline Amplitude & $\begin{array}{c}0.0031 \\
\pm \\
0.0005\end{array}$ & $\begin{array}{c}0.0019 \\
\pm \\
0.0002\end{array}$ & $\begin{array}{c}0.004 \\
\pm \\
0.0003\end{array}$ & $\begin{array}{c}0.0023 \\
\pm \\
0.0004\end{array}$ & $\begin{array}{c}0.0017 \\
\pm \\
0.0002\end{array}$ & $\begin{array}{c}0.0043 \\
\pm \\
0.0008\end{array}$ & $\begin{array}{c}0.0071 \\
\pm \\
0.002\end{array}$ & $\begin{array}{c}0.0052 \\
\pm \\
0.0009\end{array}$ & $\begin{array}{c}0.011 \\
\pm \\
0.001\end{array}$ & $\begin{array}{c}0.0049 \\
\pm \\
0.001\end{array}$ & $\begin{array}{c}0.002 \\
\pm \\
0.0002\end{array}$ & $\begin{array}{c}0.0097 \\
\pm \\
0.002\end{array}$ \\
\hline P1 & - & $<0.001$ & $<0.001$ & NS & 0.008 & 0.005 & - & 0.013 & $<0.001$ & 0.005 & $<0.001$ & $<0.001$ \\
\hline $\mathrm{P} 2$ & - & - & - & - & 0.002 & $<0.001$ & - & - & - & - & NS & $<0.001$ \\
\hline P3 & - & & - & - & - & - & $<0.001$ & 0.008 & $<0.001$ & 0.002 & $<0.001$ & $<0.001$ \\
\hline Tone & 0 & $\begin{array}{c}-0.023 \\
\pm \\
0.009\end{array}$ & $\begin{array}{c}0.006 \\
\pm \\
0.0007\end{array}$ & $\begin{array}{c}0.054 \\
\pm \\
0.02\end{array}$ & $\begin{array}{c}-0.069 \\
\pm \\
0.01\end{array}$ & $\begin{array}{c}-0.004 \\
\pm \\
0.0006\end{array}$ & 0 & $\begin{array}{c}-0.071 \\
\pm \\
0.02\end{array}$ & $\begin{array}{c}0.019 \\
\pm \\
0.001\end{array}$ & $\begin{array}{c}0.103 \\
\pm \\
0.006\end{array}$ & $\begin{array}{c}-0.068 \\
\pm \\
0.01\end{array}$ & $\begin{array}{c}-0.026 \\
\pm \\
0.005\end{array}$ \\
\hline P1 & - & 0.02 & 0.002 & 0.035 & $<0.001$ & NS & - & $<0.001$ & 0.002 & $<0.001$ & $<0.001$ & NS \\
\hline P2 & - & - & - & - & $<0.001$ & 0.041 & - & - & - & - & $<0.001$ & 0.002 \\
\hline P3 & - & - & - & - & - & - & - & $<0.001$ & 0.009 & 0.016 & NS & NS \\
\hline Frequency & $\begin{array}{c}0.288 \\
\pm 0.024\end{array}$ & $\begin{array}{c}0.301 \\
\pm 0.026 \\
\end{array}$ & $\begin{array}{l}0.315 \\
\pm 0.02 \\
\end{array}$ & - & $\begin{array}{c}0.26 \\
\pm 0.03 \\
\end{array}$ & $\begin{array}{l}0.261 \\
\pm 0.08 \\
\end{array}$ & $\begin{array}{c}0.304 \\
\pm 0.035\end{array}$ & $\begin{array}{l}0.324 \\
\pm 0.05 \\
\end{array}$ & $\begin{array}{c}0.32 \\
\pm 0.038 \\
\end{array}$ & - & $\begin{array}{l}0.301 \\
\pm 0.06 \\
\end{array}$ & $\begin{array}{c}0.322 \\
\pm 0.046 \\
\end{array}$ \\
\hline P1 & - & NS & NS & - & NS & NS & - & NS & NS & - & NS & NS \\
\hline P3 & - & - & - & - & - & - & NS & NS & NS & - & NS & NS \\
\hline
\end{tabular}

values expressed as mean \pm standard deviation, $\mathrm{n}=$ number of specimens, $\mathrm{NS}=$ non-significant, $\mathrm{P} 1=$ probability of significance compared to the basal, $\mathrm{P} 2=$ probability of significance compared to A.ch, P3= probability of significance between control and diabetic groups, significant at $<0.05$. 
Retigabine after A.ch produced significant reduction in the amplitude of control corpus contractions from $0.0023 \mathrm{~mm}$ to $0.0017 \mathrm{~mm}(\mathrm{P}=$ 0.002) as regard to contractions following A.ch and from $0.0031 \mathrm{~mm}$ to $0.0017 \mathrm{~mm}(\mathrm{P}=0.008)$ as regard to the spontaneous contractility. Also, the tone was significantly reduced by $0.12 \mathrm{~mm}$ $(\mathrm{P}<0.001)$ when compared with contractions following for A.ch and by $0.069 \mathrm{~mm}(\mathrm{P}<0.001)$ when compared with basal contractions. It insignificantly decreased the frequency

In diabetic corpus, retigabine after A.ch produced significant reduction in the amplitude of diabetic corpus contractions from $0.0071 \mathrm{~mm}$ to $0.002 \mathrm{~mm}(\mathrm{P}<0.001)$ as regard to the basal contractility. Also, it significantly reduces the tone by $0.12 \mathrm{~mm} \quad(\mathrm{P}<0.001)$ in comparison with contractility after A.ch and by $0.068 \mathrm{~mm}$ $(\mathrm{P}<0.001)$ as regard to the spontaneous contractility. It produced insignificant reduction in the amplitude compared with contractility following A.ch and in-significant reduction in the frequency.

\section{Effect of XE-991 on basal and A.Ch stimulated corpal motility: Table (2)}

XE-991 significantly increased the amplitude of control gastric corpus contractility from $0.0031 \mathrm{~mm}$ to $0.004 \mathrm{~mm}(\mathrm{P}<0.001)$. The tone is significantly increased by $0.006 \mathrm{~mm}(\mathrm{P}=0.002)$. It produces insignificant increase in the frequency XE-991 also significantly increased the amplitude of diabetic gastric corpus contractility from 0.0071 $\mathrm{mm}$ up to $0.011 \mathrm{~mm}(\mathrm{P}<0.001)$. The tone was significantly elevated by $0.019 \mathrm{~mm}(\mathrm{P}=0.002)$ but it produced insignificant increase in the frequency.

XE-991 after A.ch produced significant increase in the amplitude of control corpus contractility from $0.0023 \mathrm{~mm}$ to $0.0043 \mathrm{~mm}$ $(\mathrm{P}<0.001)$ as regard to contractions following A.ch and from $0.0031 \mathrm{~mm}$ to $0.0043 \mathrm{~mm}(\mathrm{P}=0.005)$ as regard to the spontaneous contractility. The tone was significantly reduced by $0.058 \mathrm{~mm}(\mathrm{P}=0.041)$ in comparison with contractions following A.ch but non-significantly reduced as regard to the spontaneous contractility. It insignificantly decreasesd the frequency.

In diabetic corpus, XE-991 after A.ch produced significant increase in the amplitude of contractility from $0.0049 \mathrm{~mm}$ to $0.0097 \mathrm{~mm}$ $(\mathrm{P}<0.001)$ in comparison with contractions following for A.ch and from $0.0071 \mathrm{~mm}$ to 0.0097 $\mathrm{mm} \quad(\mathrm{P}<0.001)$ as regard to the spontaneous contractility. The tone was significantly reduced by $0.129 \mathrm{~mm}(\mathrm{P}=0.002)$ when compared with contractions after A.ch but non-significant decreased by $0.026 \mathrm{~mm}$ as compared with the spontaneous contractility. It produced insignificant increases in the frequency.

\section{Discussion}

Definitely, different GI regulatory mechanisms are affected in diabetic patients like autonomic neuropathy (14), ENS disorders (3) and ICC affection (15), however, changes of other elements could also have a role in the development of DM-related GI disorders.

Potassium channels play a crucial role in many excitable tissues such as nerve and muscle cells through their activation and inhibition producing cell membrane hyperpolarization and depolarization respectively . It affect $\mathrm{Ca}^{2+}$ influx across the voltage-gated calcium channels (Cav1.2) either increase or decrease it to produce contraction or relaxation, respectively (4). Recent studies focus on the importance of $\mathrm{K}_{\mathrm{V}} 7$ (voltagedependent $\mathrm{K}^{+}$channel type $7\left(\mathrm{~K}_{\mathrm{V}} 7\right.$ or $\left.\mathrm{KCNQ}\right)$ ) channels in regulating gastro-colonic contractility. $\mathrm{K}_{\mathrm{V}} 7$ channels become active at less negative membrane potential that is close to the resting 
potential values of some GI smooth muscle cells (16).

In the last decade, a group of studies was focused on the role of $\mathrm{K}_{\mathrm{V}} 7$ channels in controlling the healthy GI smooth muscle activity $(17 ; 18 ; 19)$ but to our knowledge, no studies have been evaluated their role in controlling diabetic GI smooth muscle activity.

Therefore, the current study was designed to investigate the effect of $\mathrm{K}_{\mathrm{V}} 7$ channel modulators (Retigabine, $\mathrm{K}_{\mathrm{V}} 7$ opener \& XE-991, $\mathrm{K}_{\mathrm{V}} 7$ blocker) on Gastric motility in STZ diabetic rats as compared with healthy control.

The study revealed that, DM significantly increases the basal amplitude of gastric fundal and corpal strips contractility and only significantly increases the frequency of diabetic fundal contractions as compared to the control group. These results are consistent with Mahavadi et al. (20) who reported that fundal smooth muscle contractility obtained from mice stomach is increased when exposed to hyperglycemic medium and confirmed that oxidative stress in DM can increase RhoA expression, a GTP-binding protein, Rho kinase activity and consequently increase smooth muscle contractility. On the contrary,

James et al. (21) reported that fundal contractions are decreased while pyloric contractility is increased in diabetic mice compared to control and suggested that, these changes may have important roles in diabetic gastric dysmotility. Also, Altan et al. (22) reported that reduced fundal contractility in STZ diabetic rats is related to reduced beta adrenergic and/or serotonergic receptors activity and not related to impaired muscarinic receptor or adenyl cyclase activity while Min et al. (23) attributed that gastric dysmotility was due to impaired inhibitory nitrergic and excitatory cholinergic neuronal pathways in the stomach of diabetic patients.

The response to A.ch is significantly higher in diabetic gastric strips than the control group (Table: 1, 2; Chart 1). This is in agreement with Aihara \& Sakai (24) who reported that the contractile responses to the A.ch is increased significantly in rat gastric fundus preparations isolated 6 and 12 weeks after the onset of STZ induced diabetes which is attributed to significant increase in $\mathrm{Ca}^{2+}$ influx. Also, it is in agreement with Sakai et al. (25) attributed that to alteration of protein kinase $\mathrm{C}$ (PKC) properties, but not the density of $\mathrm{Ca}^{2+}$ channels.

$\mathrm{K}_{\mathrm{V}} 7$ opener, Retigabine, significantly decreases the spontaneous contractility of gastric fundal and corpal smooth muscle strips in diabetic and control rats but diabetic group exhibits significant more decrease in contractility than the control one (Table: 1,2; Chart 2,3,7,8). Also, retigabine significantly decreases the contractility of the cholinergic stimulated fundal and corpal strips with significant more decrease in contraction amplitude in diabetic corpus than the control one (Table: 1,2; Chart 9).

$\mathrm{K}_{\mathrm{V}} 7$ blocker, XE-991, significantly increases the spontaneous contractility of gastric fundal and corpal smooth muscle strips in diabetic and also in control rats, but diabetic group exhibits significant increase in contraction in response to XE-991 than the control one (Table: 1,2; Chart 4,5,10,11). Similar results were reported by Ipavec et al. (18) who found that XE-991 shows a significant increase in spontaneous contractions of the fundal strips in a concentration dependent way and attributed that to blockage of $\mathrm{K}_{\mathrm{V}} 7$ channels located on SMC-ICC-FLC syncytium and not by neuronal activity or excitatory neurotransmitter release. 

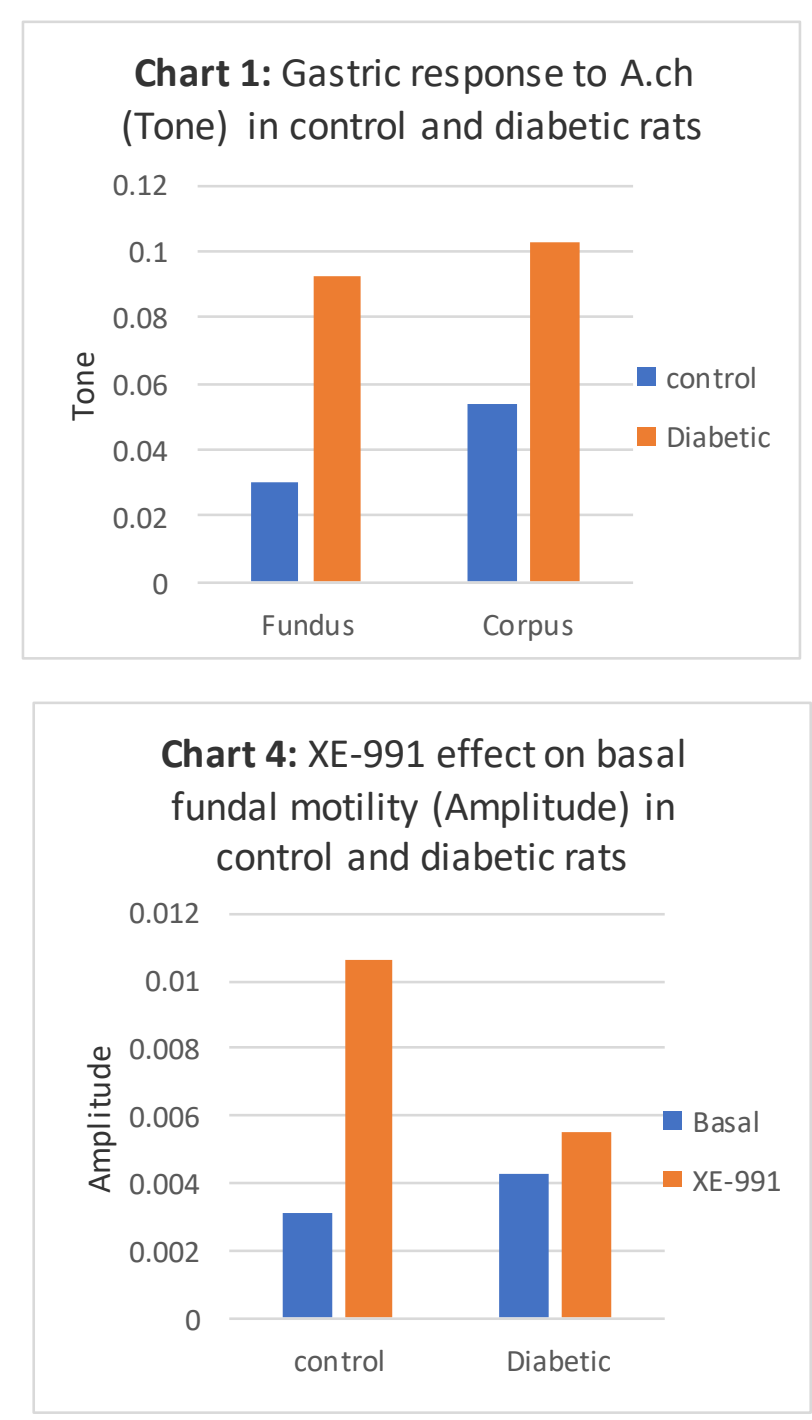

Chart 2: Retigabine effect on basal fundal motility (Amplitude) in control and diabetic rats

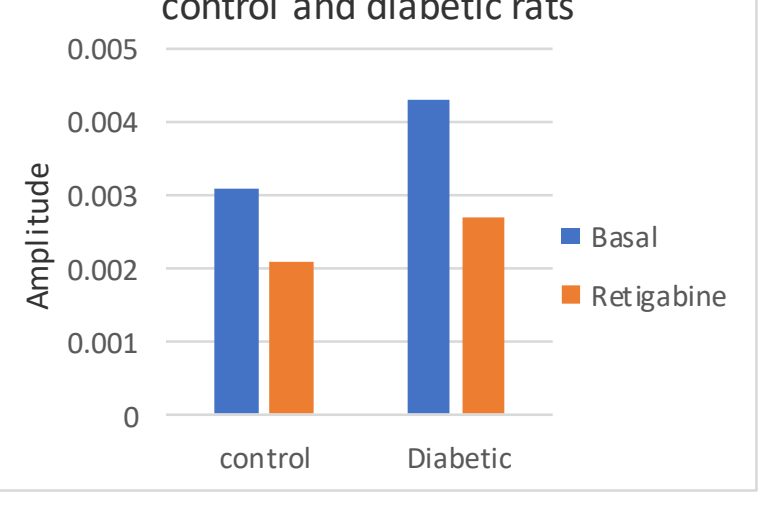

Chart 5: XE-991 effect on basal fundal motility (Tone) in control and diabetic rats

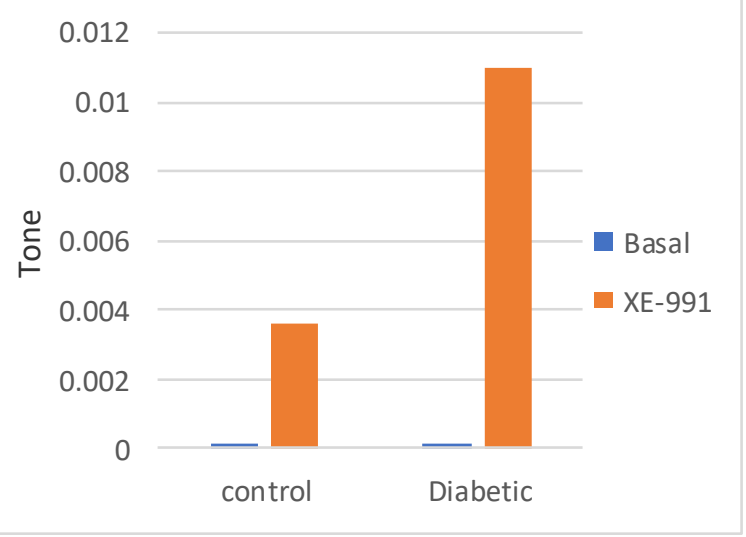

Chart 3: Retigabine effect on basal fundal motility (Tone) in control and diabetic rats

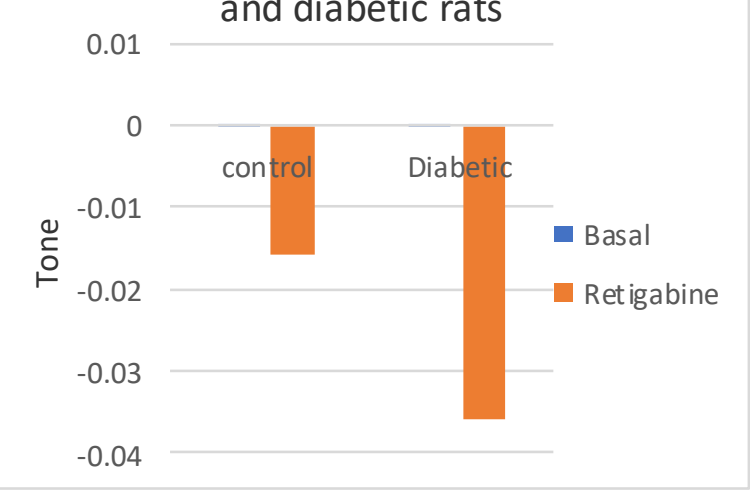

Chart 6: XE-991 effect on

cholinergic stimulated fundal motility (Amplitude) in control and

$$
\text { diabetic rats }
$$

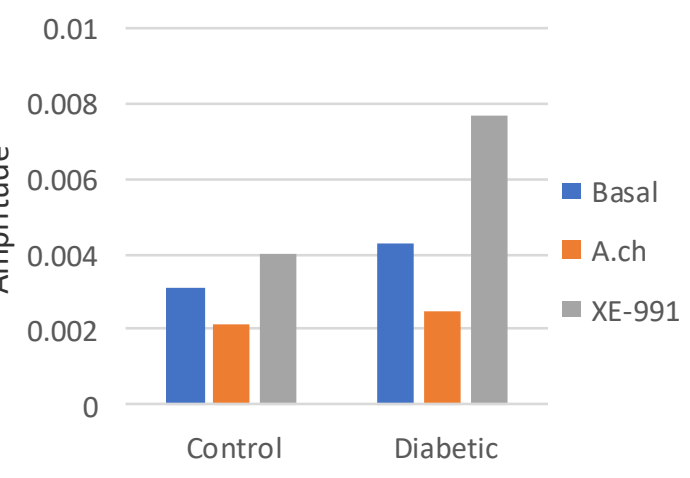



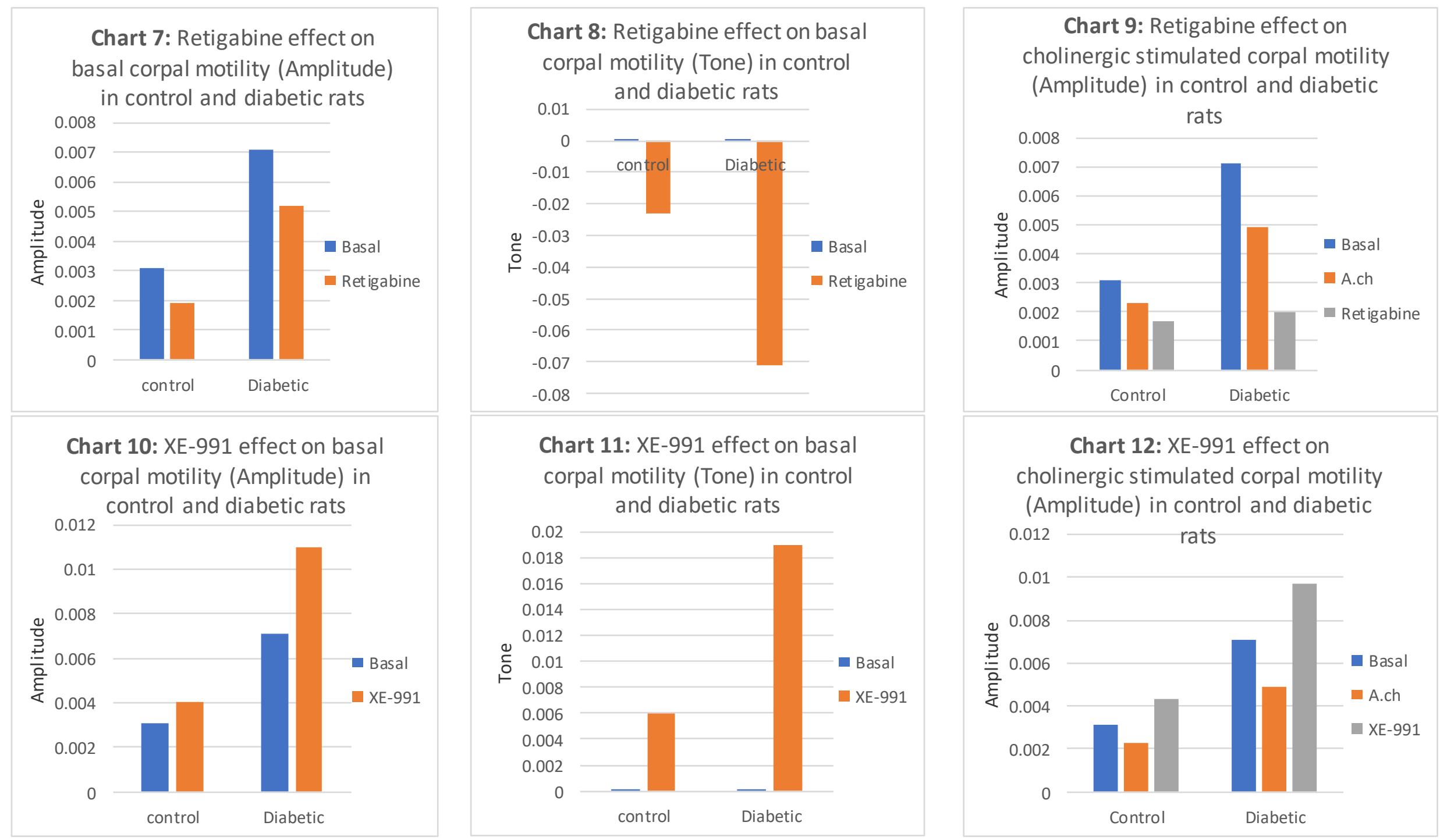

\section{Chart 12: XE-991 effect on}

cholinergic stimulated corpal motility

(Amplitude) in control and diabetic

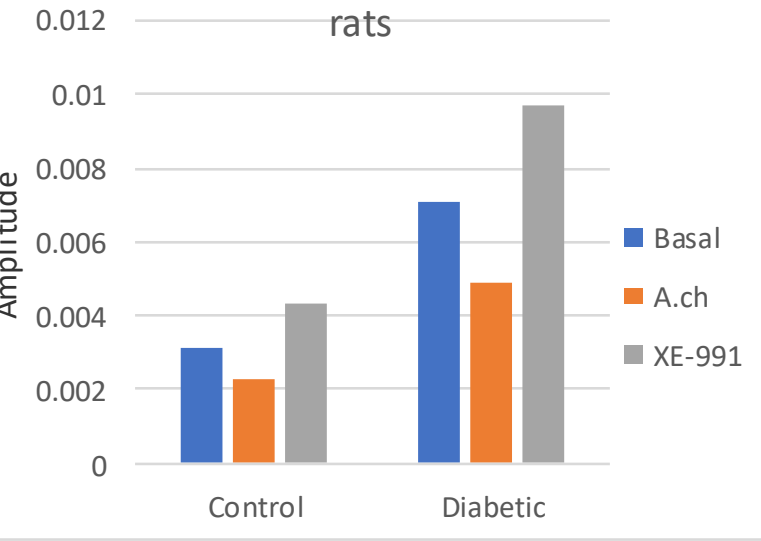


Also, XE-991 after A.ch significantly increases the amplitude of fundal and corpal smooth muscle strips contractility of both diabetic and control groups ( Table 1,2) with significant higher contraction in diabetic group (Table: 1,2; Chart 6,12). However, there is no increase in the tone after A.ch in either groups. This is in disagreement with Ipavec et al. (18) who reported that XE-991 could induce further contraction of previously contracted rat fundal muscle strips and explained it as when the muscle is contracted, membrane depolarization increases the percentage of the already opened $\mathrm{K}_{\mathrm{V}} 7$ channels in the submaximally precontracted strips compared to the resting state. By gathering the previously mentioned findings, $\mathrm{K}_{\mathrm{V}} 7$ blockers, XE-991, could stimulate the hypocontractile stomach as in diabetic gastroparesis and other gastric disorders as functional dyspepsia.

\section{Conclusion}

The study reported that, retigabine significantly decreases the basal and cholinergic stimulated contractility of diabetic fundus and corpus more than control group. XE-991 significantly increases the basal and cholinergic stimulated contractility of diabetic fundus and corpus when compared to control group.

$\mathrm{K}_{\mathrm{V}} 7$ channel modulators could affect the gastric fundal and corpal motility in type I diabetic rats, a possible new strategy that might be involved in management of diabetic gastro-enteropathy.

\section{Recommendations:}

Further research is recommended to study the protein expression of $\mathrm{K}_{\mathrm{V}} 7$ channel in diabetic GI smooth muscle. And also to study the role of $\mathrm{K}_{\mathrm{V}} 7$ channel in controlling GI motility in-vivo in type I and II diabetic animal models and also, in humans.

\section{Acknowledgements}

We would like to express our sincere gratitude to the laboratory technicians for their valuable efforts.

\section{References}

1. Maleki, D., Locke G.R., Camilleri M., Zinsmeister A. R., Yawn B. P., Leibson C. and Melton L. J. (2000) 'Gastrointestinal tract symptoms among persons with diabetes mellitus in the community', Archives of Internal Medicine, 160(18), pp. 2808-2816.

\section{Bytzer, P., Talley N.J., Leemon M., Young}

L.J., Jones M.P., Horowitz M. (2001) 'Prevalence of gastrointestinal symptoms associated with diabetes mellitus: A populationbased survey of 15000 adults', Archives of Internal Medicine, 161(16), pp. 1989-1996.

3. Yarandi, S.S. and Srinivasan, S. (2014) " Diabetic gastrointestinal motility disorders and the role of the entric nervous system : Current status and future directions" Neurogastrointrology and motility, 26(5),pp.611-626

4. Currò, D. (2014) ' $\mathrm{K}+$ channels as potential targets for the treatment of gastrointestinal motor disorders', European Journal of Pharmacology, 733(1), pp. 97-101.

5. Sanders, K. M. (2008) 'Regulation of smooth muscle excitation and contraction', Neurogastroenterology and Motility, 20(1), pp. $39-53$.

6. Currò, D. (2010) 'Voltage-gated calcium channels involved in the inhibitory motor responses and vasoactive intestinal polypeptide release in the rat gastric fundus', European Journal of Pharmacology, 628(1-3), pp. 207-213. 
7. Sanders, K. M., Koh, S. D., Ro, S. and Ward,

S. M. (2012) 'Regulation of gastrointestinal motility-insights from smooth muscle biology', Nature Reviews Gastroenterology and Hepatology, 9(11), pp. 633-645.

8. Apostolova, E., Zagorchev, P., Kokova, V., Peychev., L., (2017) 'Retigabine diminishes the effects of acetylcholine, adrenaline and adrenergic agonists on the spontaneous activity of guinea pig smooth muscle strips in vitro', Autonomic Neuroscience: Basic and Clinical, 203, pp. 51-57.

9. Vatansever U., Durmus-Altun G., Arzu Vardar S., Altaner S., Dirlik, B. (2011) 'Scintigraphic evaluation of small intestinal transit in the streptozotocin induced diabetic rats', Hippokratia, 15(3), pp. 262-264.

10. Patel R., Shah P., Deshpande S., et al. (2015) 'Fructose diet and low dose streptozotocin treatment induces the development of diabetic nephropathy in rats', Oriental Pharmacy and Experimental Medicine, 15(4), pp. 305-312.

11. Alikhani, V., Keshavarzi, Z., Hadjzadeh, M.Al.R., \& Karimi, S. (2015) 'The effect of melatonin on gastric parameters following diabetes induction in male rats', Acta Endocrinologica, 11(2), pp. 155-161.

\section{Forrest A., Molleman A., Parsons M. (2005)}

'The responses to manipulation of extracellular and intracellular calcium are altered in the streptozotocin-diabetic rat colon and ileum', European Journal of Pharmacology, 509, pp. 7783.

13. Kim, S. J., Park, J. H., Song, D. K., Park, K. S., Lee, J. E., et al. (2011) 'Alterations of Colonic Contractility in Long-term Diabetic Rat Model', Journal of Neurogastroenterology and Motility, 17(4), pp. 372-380.
14. Brock, C., Softeland, E., Gunterberg,V., Frokjaer, J.B., Lelic, D., Brock, B., Dimcevski, G., Gregerson, H., Simren.M., Drewes,A.M.(2013) "Diabetic autonomic neuropathyaffects symptom generation and braingut axis" Diabetics Care,36(11),pp.3698-3705.

15. Muangchan, N., Kooptiwut, S., Tapechum, S., Akarasereenont, P., Vongsopanagul, N., Pongwattanapakin, $K$. and Chaikomin, R. (2017) '13C-Acetic Acid Breath Test Monitoring of Gastric Emptying during Disease Progression in Diabetic Rats', Biological and Pharmaceutical Bulletin, 40(9), pp. 1506-1514.

16. Currò, D. (2016) 'The modulation of potassium channels in the smooth muscle as a therapeutic strategy for disorders of the gastrointestinal tract', Advances in Protein Chemistry and Structural Biology, 104, pp. 263305.

17. Jepps, T. A., Greenwood I. A., Moffatt J. D., Sanders K. M., Ohya S. (2009) 'Molecular and functional characterization of $\mathrm{K}_{\mathrm{v}} 7 \mathrm{~K}^{+}$channel in murine gastrointestinal smooth muscles', American Journal of Physiology-Gastrointestinal and Liver Physiology, 297(1), pp. G107-G115.

18. Ipavec, V., Martire M., Barrese V., Taglialatela M., Currò, D. (2011) 'KV7 channels regulate muscle tone and nonadrenergic noncholinergic relaxation of the rat gastric fundus', Pharmacological Research, 64(4), pp. 397-409.

19. Adduci, A., Martire, M., Taglialatela, M., Arena, V., Rizzo, G., Coco, C. and Currò, D. (2013) 'Expression and motor functional roles of voltage-dependent type $7 \mathrm{~K}+$ channels in the human taenia coli', European Journal of Pharmacology, Elsevier, 721(1-3), pp. 12-20. 
20. Mahavadi, S., Sriwai, W., Manion, O., Grider, J. R. and Murthy, K. S. (2017) 'Diabetes-induced oxidative stress mediates upregulation of RhoA/Rho kinase pathway and hypercontractility of gastric smooth muscle', PloS one, 12(7), pp. e0178574.

21. James, A. N., Ryan, J. P., Crowell, M. D. and Parkman, H. P. (2004) 'Regional gastric contractility alterations in a diabetic gastroparesis mouse model: effects of cholinergic and serotoninergic stimulation', American Journal of Physiology-Gastrointestinal and Liver Physiology, 287(3), pp. G612-G619.

22. Altan, V. M., Yildizoğlu, N. and Oztürk, Y. (1987) 'Decreased gastro-intestinal responses to certain agonists in streptozotocin- and alloxandiabetic rats in vitro', Pharmacology, 34(2-3), pp. 143-148.

23. Min, Y. W., Ko, E., Lee, J. and Rhee, P. (2018) 'Impaired neural pathway in gastric muscles of patients with diabetes', Scientific Reports, 8(1), pp. 7101.

24Aihara, K. and Sakai, Y. (1989) 'Hyperreactivity of contractile response in gastric fundus smooth muscle from rats with diabetes induced by streptozotocin', Archives internationales de pharmacodynamie et de therapie, 302, pp. 220-231.

25. Sakai, Y., Inazu, M., Shamoto, A., Zhu, B. and Homma, I. (1994) 'Contractile hyperreactivity and alteration of PKC activity in gastric fundus smooth muscle of diabetic rats', Pharmacology Biochemistry and Behavior, Elsevier, 49(3), pp. 669-674. 